IZA DP No. 1088

The Economic Experiences of Refugees in Canada

Don DeVoretz

Sergiy Pivnenko

Morton Beiser

March 2004 


\title{
The Economic Experiences of Refugees in Canada
}

\author{
Don DeVoretz \\ IMER, Malmo University, \\ RIIM, Simon Fraser University and IZA Bonn \\ Sergiy Pivnenko \\ RIIM, Simon Fraser University \\ Morton Beiser \\ CERIS, University of Toronto
}

Discussion Paper No. 1088
March 2004

IZA

P.O. Box 7240

53072 Bonn

Germany

Phone: +49-228-3894-0

Fax: +49-228-3894-180

Email: iza@iza.org

\begin{abstract}
Any opinions expressed here are those of the author(s) and not those of the institute. Research disseminated by IZA may include views on policy, but the institute itself takes no institutional policy positions.

The Institute for the Study of Labor (IZA) in Bonn is a local and virtual international research center and a place of communication between science, politics and business. IZA is an independent nonprofit company supported by Deutsche Post World Net. The center is associated with the University of Bonn and offers a stimulating research environment through its research networks, research support, and visitors and doctoral programs. IZA engages in (i) original and internationally competitive research in all fields of labor economics, (ii) development of policy concepts, and (iii) dissemination of research results and concepts to the interested public.
\end{abstract}

IZA Discussion Papers often represent preliminary work and are circulated to encourage discussion. Citation of such a paper should account for its provisional character. A revised version may be available on the IZA website (www.iza.org) or directly from the author. 
IZA Discussion Paper No. 1088

March 2004

\section{ABSTRACT}

\section{The Economic Experiences of Refugees in Canada}

Canada admits refugees on the basis of compassion and not economic criteria. It is however, important to document the economic successes or failures among Canada's refugee population in order to understand how post arrival integration policies affect refugee economic performance. This essay examines a set of economic indicators from Canada's IMDB database to assess the post 1981 Canadian refugee economic experience. With the aid of a standard human capital model we answer a series of economic questions including the length of time required for refugee economic integration, their use of Canada's social safety net, refugee poverty levels and refugee economic performance vis-à-vis Canada's family immigrant class. Our main findings are that employed Canadian refugees earn an amount equal to that earned by their family class reference group circa 1980-2001. However, the incidence of social assistance attachment for refugees is substantial and for those refugees who receive any assistance their total income is at the near destitute level.

JEL Classification: J61

Keywords: refugees, immigrant earnings, human capital

Corresponding author:

Sergiy Pivnenko

Centre of Excellence

WMX 4647

Simon Fraser University

Burnaby, BC, V5A 1S6

Canada

Email: spivnenk@sfu.ca 


\section{Introduction}

Canada's immigration and refugee legislation admits permanent residents through a variety of gateways which all require prior assessment to qualify for admission. This paper concentrates on the economic performance of refugees. As one of more than 150 signatories to the UN Convention on refugees, Canada is committed to protecting the persecuted and stateless. Canada is also one of a much smaller group of Convention signatories who offer not just temporary protection, but the option of permanent resettlement. Humanitarian concerns presumably motivate the decision to offer refugees the opportunity for permanent resettlement, and such concerns probably provide sufficient justification to perpetuate this policy. Critics, however, suggest that the policy is misguided, because it brings grave economic consequences in its wake. This paper addresses these concerns by investigating the question: what are the labour market outcomes for refugees in Canada?

Those refugees who arrive in Canada must meet several criteria. Convention refugees are people who leave their country because of a well-founded fear that they will be persecuted due to their religious beliefs, race, nationality, political opinion or membership in a persecuted group. In addition to Convention refugees, Canada has been admitting Protected Persons, ${ }^{1}$ that is, asylum seekers and inhabitants of designated refugee-producing countries. Asylum seekers are defined as those persons "seriously and personally affected by: civil war, armed conflict, or massive violations of human rights." Inhabitants of the designated countries ${ }^{2}$ meet the definition of Convention refugees, and can include people who suffer because their country denies them the rights of freedom of expression, dissent, or the right to engage in trade union activity. However, unlike Convention refugees or asylum seekers, the latter group must apply for resettlement from outside Canada. These refugee applicants are admitted under special rules and are considered either a Convention refugee or a member of a humanitarian designated class.

The humanitarian designated class was introduced by the federal government in 1997 to provide for the possibility of resettlement to individuals personally or seriously affected by situations including civil war and armed conflict. Refugees may be selected abroad for

\footnotetext{
${ }^{1}$ Under the 2002 legislation, or the Immigration and Refugee Protection Act this entry group is now referred to as the Humanitarian Designated Classes.

${ }^{2}$ List of countries posted on CIC web site at www.cic.gc.ca/english/refugees/resettle-5.html.
} 
resettlement in Canada or may apply for and receive Convention refugee status from the federal Immigration and Refugee Board within Canada. Finally, it is important to note that Canada's refugee assessment contains no economic criteria for entry.

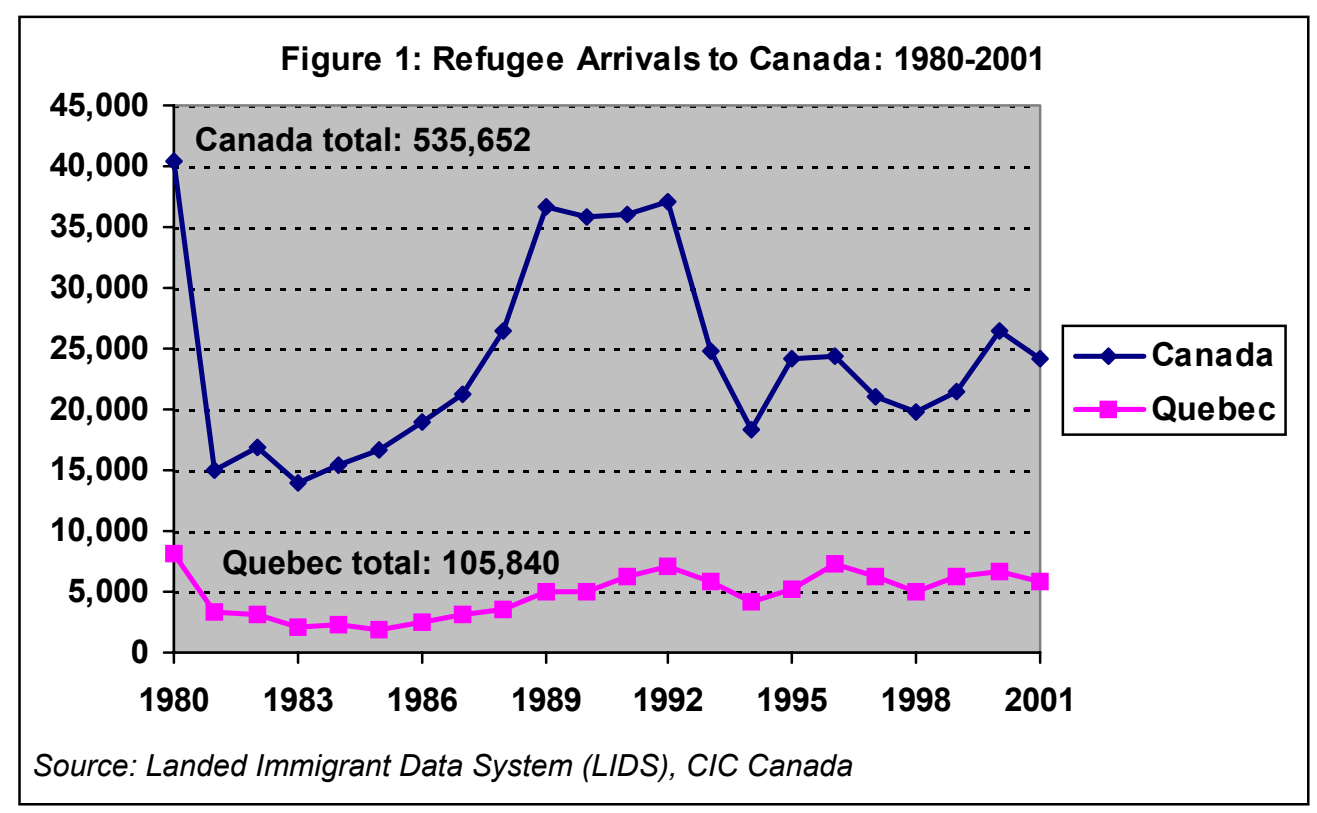

Between 1980 and 2001 Canada received a total of 535,131 refugees from a wide variety of source countries. Figure 1 documents dramatic fluctuations in refugee arrivals between 1980 and 2001, with numbers ranging from a high of 40,000 in 1980 (corresponding to the "Boat People" crisis in Southeast Asia which stimulated the largest admission of refugees in Canada's history) to a low of 15,000 in 1983. Since Canada does not have an explicit or implicit refugee quota, the total number of yearly refugee arrivals is a product of both external events and Canada's overall yearly immigrant target levels. The fall in refugee levels in the 1980's and the rise in the early 1990's largely mimics the movement of total announced immigration targets. During the last seven years, the number of refugee arrivals has become stabilized at fewer than 25,000 per year, roughly ten percent of the immigrant total.

Figures 2 and 3 also provide a mirror of the socio-political hot spots of a given era, demonstrating the manner in which changing world conditions influence refugee flows to Canada. During the period 1980-1995, Southeast Asia, Poland and El Salvador accounted 
for more than half of all refugee admissions. By contrast, between 1995 and 2000, people from Bosnia Herzegovina, Sri Lanka, Somalia and the Middle East made up 54 percent of all such admissions.

Figure 2: Refugee Arrivals to Canada in 1980-1994 by Source Country

Total: 373,867 arrivals

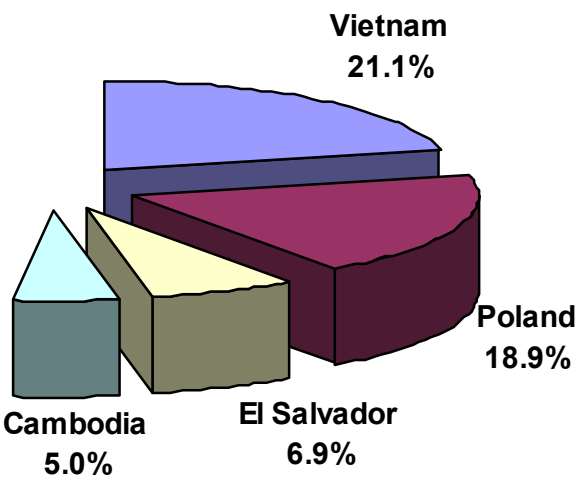

Source: Landed Immigrant Data System (LIDS), CIC Canada 


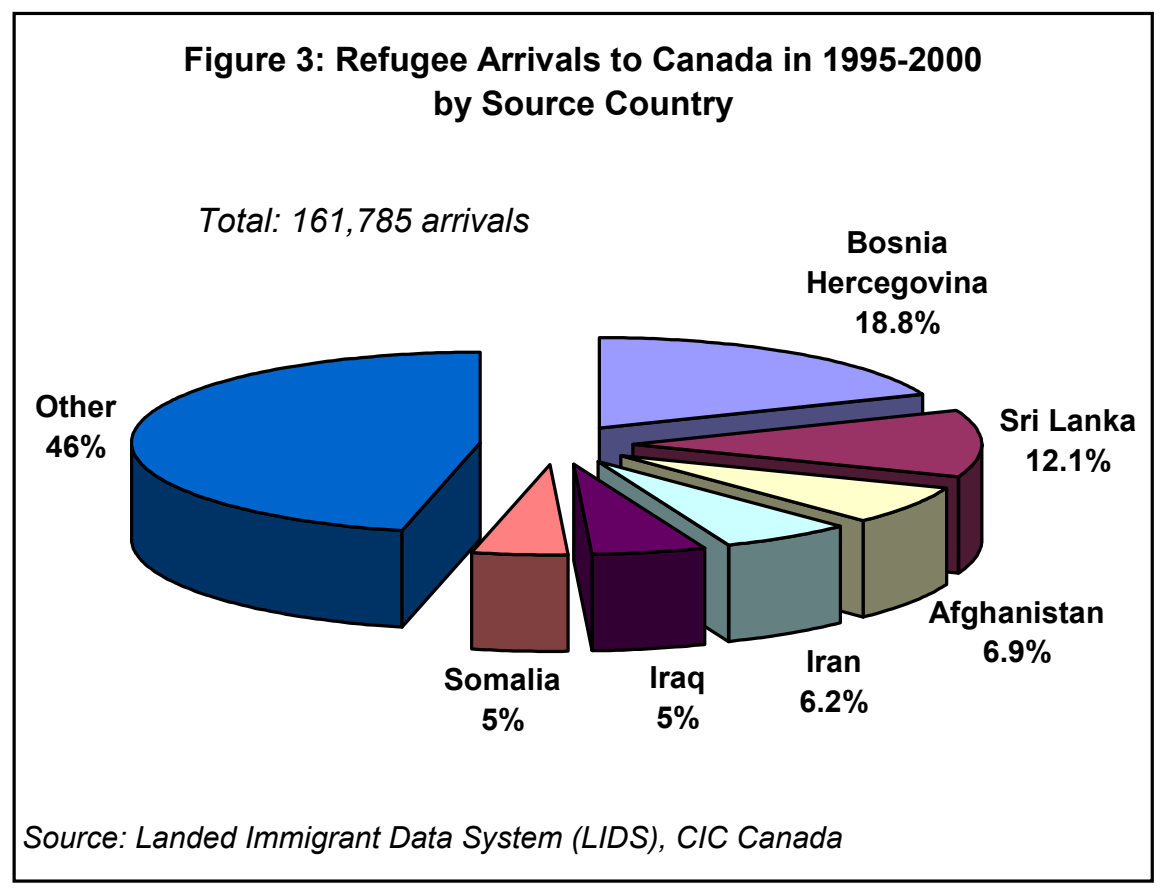

Given this dramatic and fluctuating number of refugee claimants and their heterogeneity across source countries it is appropriate to ask how these various refugee groups fared over time in the Canadian economy. The central goal of this essay is to answer this question.

This paper proposes to analyze the economic performance of Canadian refugees in terms of the standard human capital model. This model basically states that individuals prior to or after arrival in Canada differentially invest in themselves to increase their endowment of human capital (education and language) depending on their age and ability. In turn, differential rates of investment by individuals lead to different economic outcomes in the labor market. In addition to human capital investment, Canadian immigration selection policy influences the ultimate economic outcome of refugees and immigrants. In the Canadian context, foreign arrivals can enter across three broad gateways, the independent or economic class, via a family reunification gateway or by refugee designation. ${ }^{3}$ From an

\footnotetext{
${ }^{3}$ The economic or independent class is further subdivided into principal applicants and dependents. Only the principal applicants are assessed for their potential economic contribution under Canada's points system. Thus, they constitute the doubly selected group. The accompanying minors or the spouse of the principal applicant of the spouse are not assessed but can not enter Canada unless the principal applicant passes the second selection
} 
economic viewpoint the government's designation of the assessment gateway influences the economic outcomes of the foreign born. In fact, most foreign arrivals to Canada, including refugees, are not economically screened by Canada but are singly selected. ${ }^{4}$ In short, those who self-select to leave home, but experience no further economic screening upon arrival to Canada will be referred to in this paper as singly selected. ${ }^{5}$ Double selection in the immigrant literature argues that the immigrant first self-selects by leaving, and then the destination country will select them again if the immigrant offers himself as an economic or independent mover. ${ }^{6}$ This second selection based upon human capital attributes of the Canadian bound economic immigrants, presumably leads to their speedier integration into the Canadian economy. In turn, the condition of the Canadian economy at the refugee's or immigrant's time of arrival is often an important influence on their ultimate economic success. ${ }^{7}$

Given that refugees are selected under the sole criterion of humanitarian compassion with presumably little consideration given to their human capital attributes, very few economists have analyzed Canadian refugee economic performance to date. Several relevant economic questions arise, which we would like to address. These include:

\section{Do refugees experience economic integration after a period of time in Canada?}

2. How does the refugee economic experience compare to Canada's other singly selected immigrant group or the family class?

3. Does a refugee's economic performance depend on which particular refugee gate she/he entered?

4. Does the year of arrival and the associated macro-economic conditions affect the economic performance of refugees?

\footnotetext{
procedure. Thus, this paper will treat all members of the independent class, both principal members and their dependents as doubly screened.

${ }^{4}$ In fact, only $17 \%$ of all arrivals (none refugees) must pass economic criteria to earn 65 plus points on human capital attributes prior to admission.

${ }^{5}$ Clearly, Canada attempts in insure that the bone fides exist for self proclaimed refugees, but in terms of their economic outcome there is no explicit selection technique employed by Canada to gain admission. This also holds for the family class of immigrants.

${ }^{6}$ The 2002 Immigration and Refugee Protection Act (IRPA) of 2002 made some substantial changes in both economic criteria for entry of the economic class and the adjudication of refugees. However, all the refugee arrivals under study in this paper were admitted under the 1978 Immigration Act. See Yan Shi 2003) for complete details of both the 1978 and 2002 Immigration Acts.

${ }^{7}$ This is termed the scarring effect. If the economy is weak upon arrival then many immigrants never experience the economic "catch-up" that immigrants who arrive in economically robust periods experience.
} 
5. How many refugees remain below the low-income or poverty line after seven years in Canada?

6. What is the refugee social assistance and employment insurance experience given the answer to question 5?

The primary purpose of the remaining portions of this essay is to answer these questions and arrive at an overall conclusion on Canadian refugee economic integration. To do this end, we next provide some stylized facts about the human capital characteristics of refugees. Given this background we then report refugee earnings and their relative rates of economic integration into the Canadian economy after arrival and their use of Canada's social safety net. Finally, we conclude our study by answering the above posed questions and assess Canadian refugee economic integration in general.

\section{Literature Review}

The academic literature has primarily focused on legal or political issues of refugee claimants in Canada. Thus, the economic performance of refugees has received little attention.

Research with the "Boat People," Southeast Asian refugees from Vietnam, Laos and Cambodia (Beiser 1999; Caplan, Whitmore and Choy 1989; Haines 1987; Strand 1989; Fass 1986) who were admitted to the U.S. and Canada suggests that, after an initial decade of economic struggle, refugee employment rates approximate, and perhaps better those of the receiving society and that refugee service demands are lower. Because these studies have focused on a particular group of refugees who arrived in North America during a particular historical era, the conclusions are necessarily limited.

This lack of a comprehensive studies on the economic status of refugees partially owes to inadequate census data. Census data in the U.S. or Canada only discloses foreign birth status and does not reveal entry status (e.g. refugee, family class immigrant, etc.) of an 
immigrant and thus precludes any detailed economic analysis of the refugee sub-group. Nonetheless, some imaginative census based work has been reported. ${ }^{8}$

A more reliable data source is available to refugee scholars in Canada.

The Longitudinal Immigration Data Base (IMDB) combines information from landing records compiled by Citizenship and Immigration Canada (CIC) with information from refugee or immigrant personal income tax returns. If we combine these two data sets we can track income performance of different immigrant admission categories including refugees after 1980. However, education, occupation and official language ability are recorded as "tombstone" information. In other words, the values of these variables are only known at the time of the refugee's landing date. ${ }^{9}$

The IMDB data set allows an economic analysis across entry categories of immigrants over a sufficiently long enough time period to identify cohort, period and aging affects on differential refugee economic outcomes.

A CIC (1998) utilizing the IMDB database revealed important differences (and some similarities) in the labour market behavior of Canada's major immigrant admission categories. ${ }^{10}$ An important example of both differential and then converging behavior is the finding that although Canadian refugees reported substantially lower employment earnings than economic applicants, their earnings patterns relative to three other immigrant entry categories were very similar. ${ }^{11}$ Moreover, refugees who had been in Canada for twelve or more years reported average employment earnings at or near the Canadian-born average. Nonetheless, this study reported that refugees admitted prior to 1990 typically reported the highest rates of unemployment benefit usage when compared to any other immigrant category or the Canadian-born population. Also after two years in Canada refugees again report the highest rates of social assistance usage.

\footnotetext{
${ }^{8}$ For example, in the U.S. Cortez (2001) used the 1980 and 1990 U.S. censuses to generate a synthetic panel of refugee and economic immigrants. Even with these limitations, Cox found that refugees have higher rates of human capital accumulation and thus even though their earnings start below other U.S. immigrants their annual earnings grow faster than these immigrants. This finding reinforces our earlier contention that educational attainment is crucial in determining refugee earnings.

${ }^{9}$ Some tombstone data, age at arrival, years in Canada can be extrapolated into the future.

${ }^{10}$ These groups included the family class, economic principal applicants, the spouses and dependents of these economic principal applicants, and refugees.

11 These immigrant groups included the family class, and the spouses and dependents of economic principal applicants.
} 
Using a very restrictive sample size DeSilva (1997) employed a IMDB sub sample of male immigrants who landed during the period 1981-1984 to test the commonly held belief that Canadian refugees perform poorly when compared to Canadian immigrant groups. His analysis was restricted to four immigrant entry classes: independents, assisted relatives, Convention refugees, and the designated class, the last two being combined into one group for the purposes of regression analysis. DeSilva found that although independently selected immigrants were the highest foreign-born income earners, they experienced the smallest earnings growth after arrival. In contrast, the designated refugee class reported the most rapid increase in earnings.

Overall, DeSilva's study demonstrated a rapid convergence in earnings among immigrants and refugees over time. Although the refugee and assisted relative classes initially showed a significant earnings disadvantage compared with the independents, the gap narrowed over time. Given that refugees had the weakest language ability upon landing, their economic progress was deemed strong.

DeSilva also employed an Oaxaca decomposition technique, which revealed that differences between refugee and immigrant human capital endowments at the time of landing account for only a small portion of the earnings differentials that exist across these groups. This implies that one has to look at some factors other than educational and demographic characteristics at arrival to explain the observed earnings differentials.

Finally, DeSilva argues that the economic success of refugees was highly conditioned on their region of origin. The most successful among them were those from Europe, whereas many of refugees from Africa and Southeast Asia have performed poorly.

Beiser and Hou (2000), using the data from the Refugee Resettlement Project (RRP), examined gender differences in the English language acquisition and male-female differences in the employment consequences of language proficiency of refugees. The results of the study confirmed that English proficiency was a significant determinant of the likelihood of unemployment and labour force participation in the long term.

In sum, the extant literature on Canadian refugee economic performance points to the use of the IMDB as the primary data source for this analysis. In addition, these studies argue that earnings convergence occurs between refugees and any reference group over time (12 
years) with educational attainment and language acquisition conditioning the speed of convergence. We will explore this presumed earnings convergence in more detail in the following section.

\section{Stylized Facts}

Canadian researchers are fortunate in having at their disposal two administrative data bases that when combined yield the researcher a portrait of the immigrant upon arrival (LIDS) and records his/her economic performance while residing in Canada (IMDB). The LIDS or landings records are exhaustive and cover every permanent legal immigrant to Canada who arrived after 1980. It is a snapshot that records various socio-economic and demographic features upon arrival. Our version of LIDS covers 4.1 million entrants between 1980 and 2001. The IMDB or immigration database combines both the LIDS database to the immigrant's yearly tax records. This administrative database only covers immigrants who file income tax and hence the coverage is limited to 40-50 percent of all past arrivals. We will employ this data set to generate some stylized facts below and in our more extensive analysis in the next section. ${ }^{12}$

The human capital attributes of refugees varied considerably and was, to some extent a reflection of educational opportunities available in refugee producing countries.

\footnotetext{
${ }^{12}$ The IMDB has one major weakness, namely the disappearance of immigrants over time through death, emigration or retirement but otherwise provides a time series picture of refugee and immigrants.
} 
Figure 4: Educational Qualifications of Foreign-born by Entry Class and Source Region: 1980-2001 arrivals

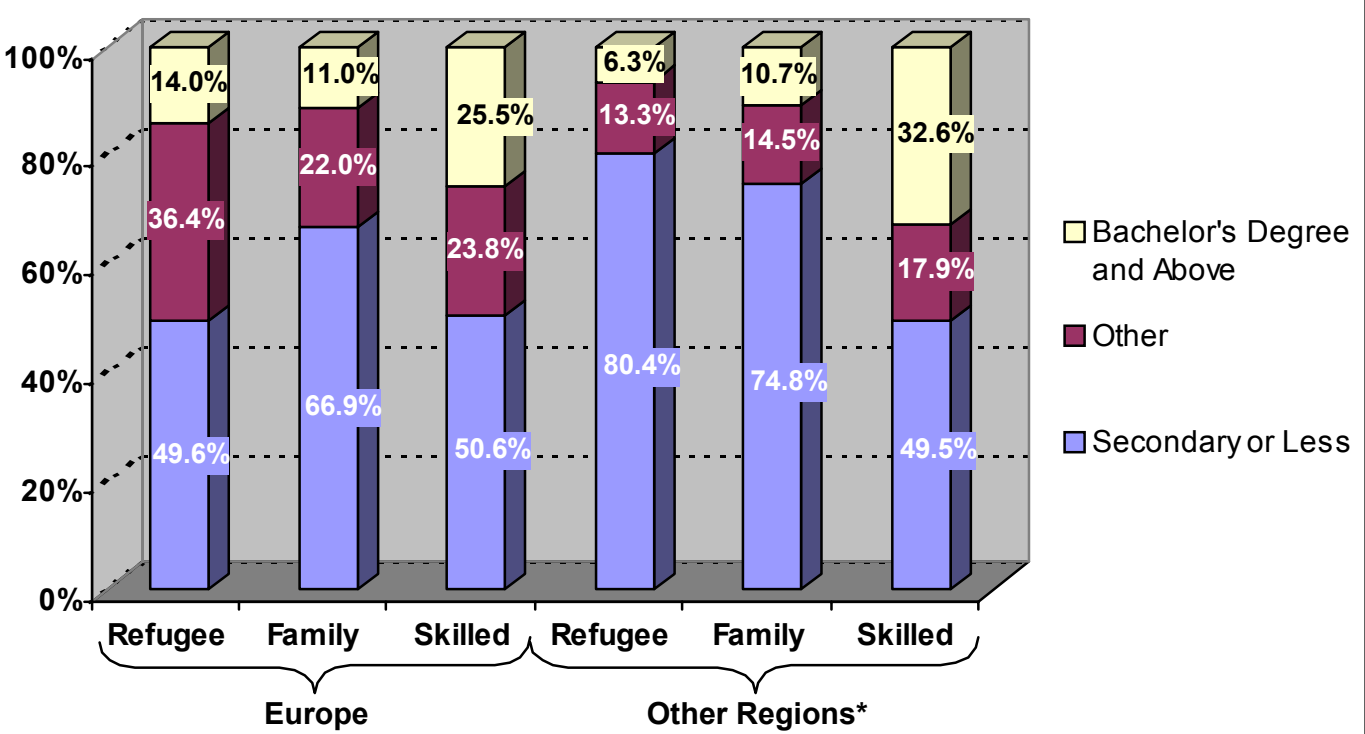

Source: Landed Immigrant Data System (LIDS), CIC Canada *United States excluded

Figure 4 illustrates the influence of source area on educational heterogeneity. For example, approximately fifty per-cent of refugees from Europe who arrived between 1980 and 2001 had some post-secondary education compared to only 20 percent who came from other regions. ${ }^{13}$ If we compare the educational attainment levels for European refugees across entry gates we can see that refugees from Europe were as well educated as skilled Canadian immigrants in general. Refugees from non-European sources were the least educated of all immigrant classes: 80 percent had no more than a secondary level of education.

\footnotetext{
${ }^{13}$ The reported percentages for greater than post-secondary educational levels for Africa (28\%), Asia (23\%) and South and Central America (25\%) were all about half the European level.
} 


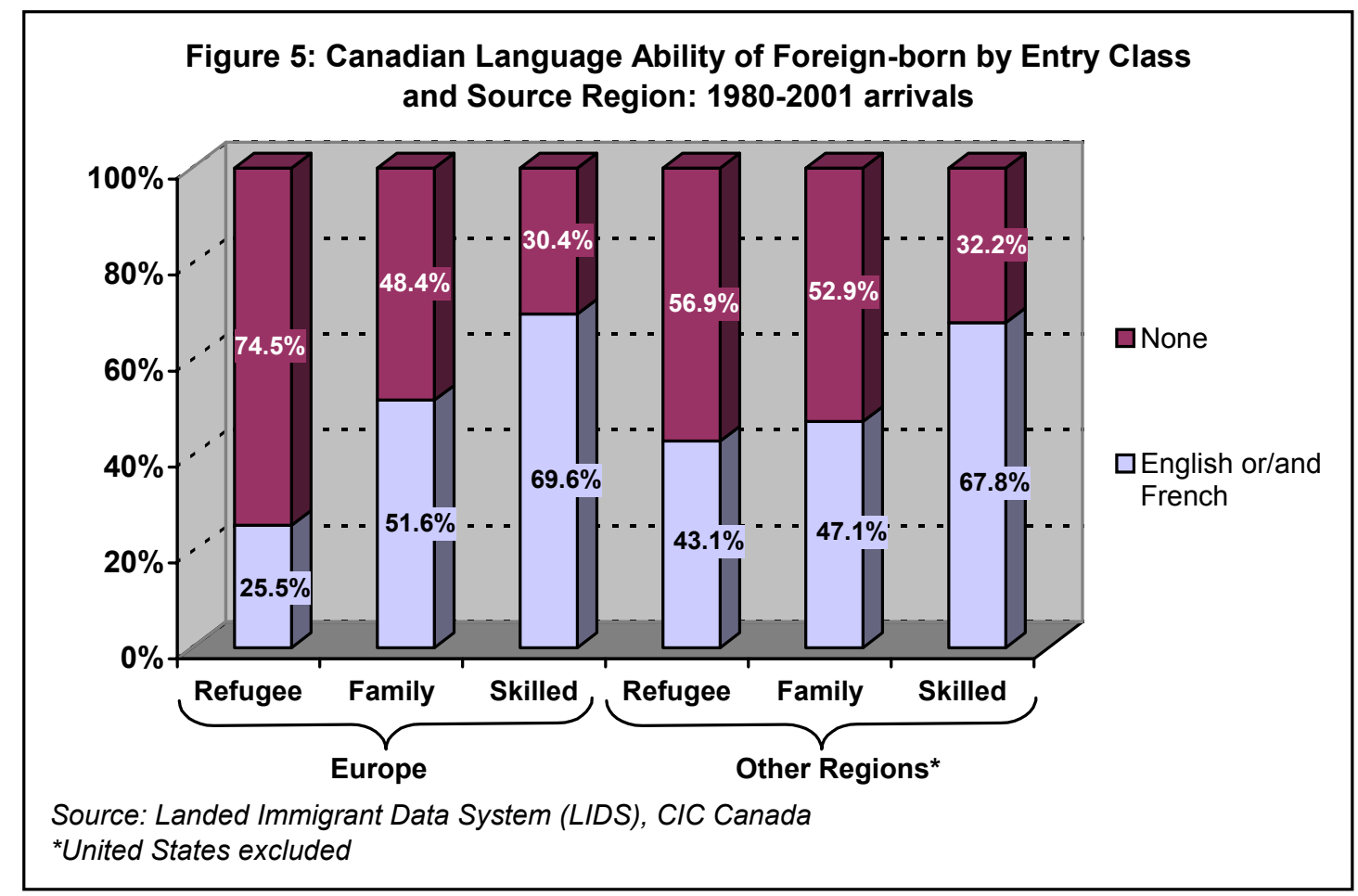

Knowledge of Canada's official languages followed a different pattern (Figure 5). English or French language ability is one of a number of ways in which applicants for independent immigrant status can earn enough points to qualify for admission. As a consequence, the fact that - regardless of source region - almost 70 percent of all immigrants in this category spoke at least one of Canada's official languages is not surprising. The proportion of family class immigrants who spoke either English or French was slightly lower - about 50 percent - a proportion which, once again, did not vary by source region.

Refugees were less likely to have a command of English or French than other immigrant classes: however, the group least likely to possess this advantage was refugees from Europe. Further analysis (not shown) demonstrated the uneven distribution of official language ability across refugee groups: 75 percent of refugees from Europe spoke neither of Canada's official languages, in comparison with 57 percent of refugees from other regions who spoke neither language.

A consideration of Figures 4 and 5 allow a comparison of educational and linguistic skills for Canada's family and refugee classes circa 1980-2001. The comparisons are striking. 
European refugees were more highly educated than either independent or family class immigrants from this region, but were more likely to be linguistic disadvantaged. For nonEuropean family class members the educational attainments and linguistic skills are near identical to non-European refugee attainments. In sum, European refugees are a unique group in terms of higher educational levels and less linguistic skills. These differential human capital endowments of education and language should affect refugee economic performance, which we will document below.

\section{Refugee Economic Outcomes - Economic Outcomes: Entry Cohorts and Immigrant Admission Categories}

The IMDB data set allows us to analyze the economic outcome of refugees from several dimensions. Essentially, the methodology employed here is to identify a class or type of earnings (e.g. employment income, social assistance) and ask how did the refugee group who reported this type of earnings fare vis-à-vis other entry categories. We will also expand this analysis by computing refugee total income, that is we combine the refugee's target income (e.g. employment earnings) with all other sources of earnings (self-employed, social assistance, etc.) reported for the refugee.

Figure 6 presents an overview of total earned income by all employed refugees seven years after arrival for three different cohorts based on date of arrival: 1980, 1985 and $1990 .^{14}$ A further distinction is made to isolate regional differences by specifying the earnings of refugees in Canada and for the province of Quebec. This figure allows us to detect if there is an entry or period effects. In other words, has the earned income prospects of refugees changed between those refugees who entered in the 1980 or 1990s? The answer is no, since seven years after their respective arrival dates the 1980 and 1990 refugee cohorts reported near identical earned incomes. A period affect nevertheless appears in 1992 when refugees for the 1985 cohort earned about $\$ 2,000$ more (1992 constant dollars) after seven years in Canada than either the 1980 or 1990 cohorts. Thus, although no long-term decline in refugee earned income appears after 1980, it was better to have arrived before Canada's recession. In

\footnotetext{
${ }^{14}$ Figure 6 reports total income from all sources for refugees who reported employment earnings.
} 
addition, Figure 6 clearly portrays the economic penalty for refugee settlement in Quebec. We return to the cause of this $15 \%$ provincial penalty in a later section. ${ }^{15}$

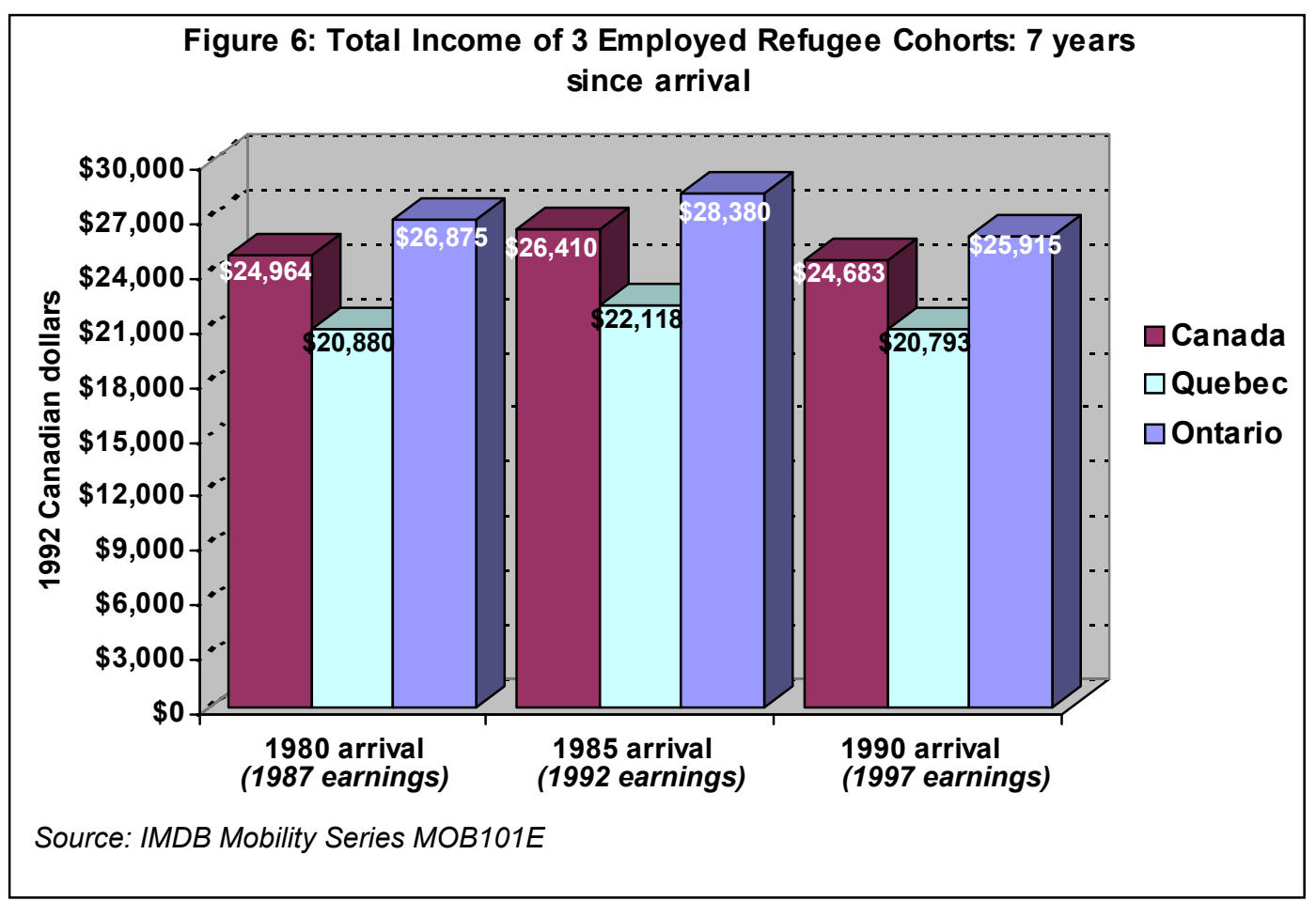

We argued above that how the refugee entered may ultimately affect his/her degree of economic integration (linguistic and human capital levels) and in turn affect their economic outcomes. Figures 7-A, 7-B and 7-C report the differential earnings across three subdivisions of refugee entry gates for three entry periods. Each refugee gate reflects a presumed different degree of sponsorship or support mechanism after arrival in Canada. In short, those refugees who fall in the category "In Canada" are self-sponsored asylum seekers. The remaining two categories, Private and Government, reflect respectively the presence of a Canadian sponsor in the private or public sector. Given our above arguments we would expect that sponsored refugees would after seven years do better economically than asylum seekers who lack some of these support mechanisms. A clear pattern emerges in favor of the privately sponsored

\footnotetext{
${ }^{15}$ This provincial difference could arise because of the Quebec economy's weakness or the weak endowment of human capital found in Quebec refugees or both.
} 
refugee group since between 1987 and 1997 the income prospects of Canadian refugees changed dramatically by refugee entry gates. The "In Canada" or asylum-seeking refugees experienced a 20 percent decline in constant 1992 dollars even after allowing for a sevenyear integration period. Government-sponsored refugees experienced a more modest decline over this period $(-12 \%)$ while privately sponsored refugees had a modest five percent rise in their earnings.
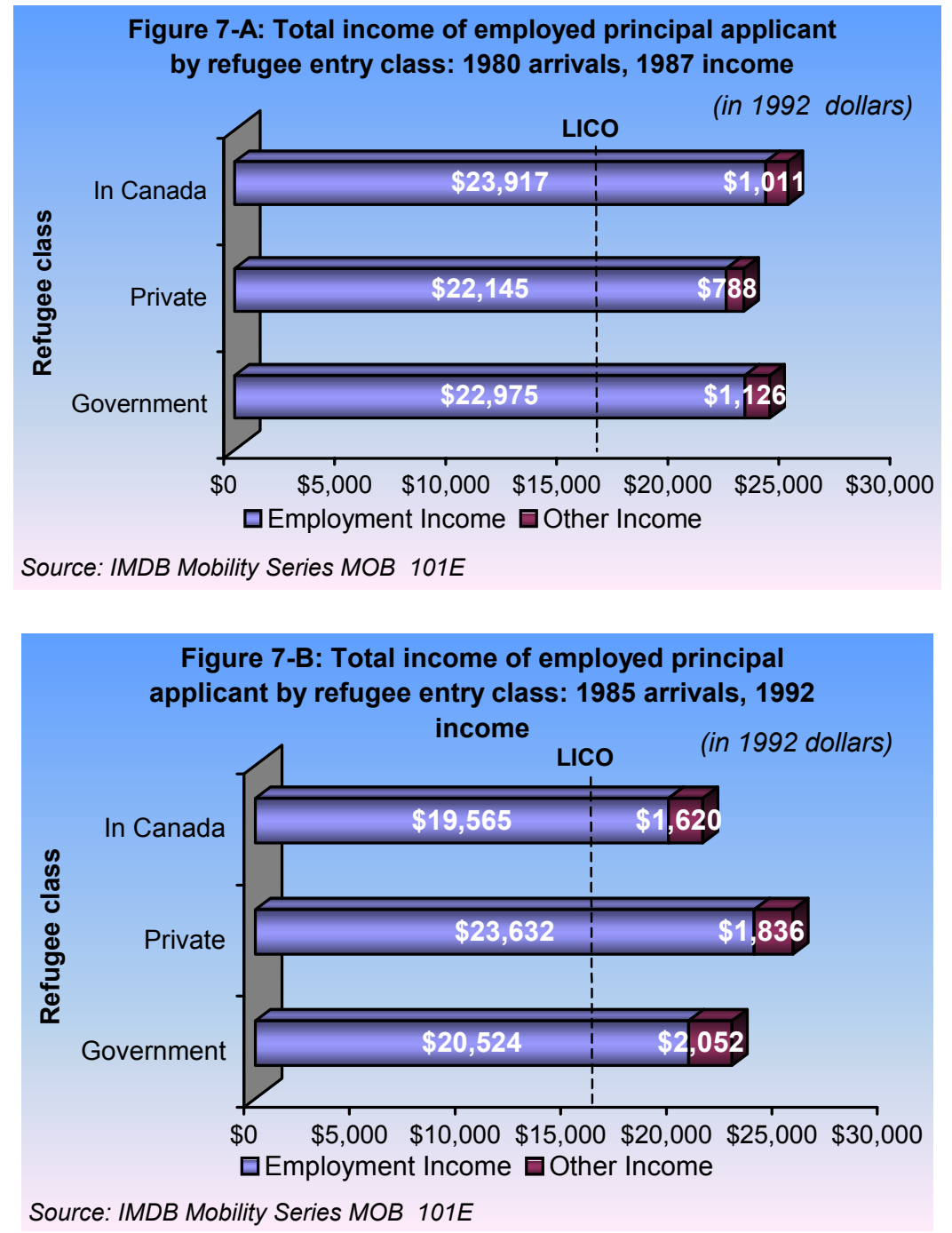


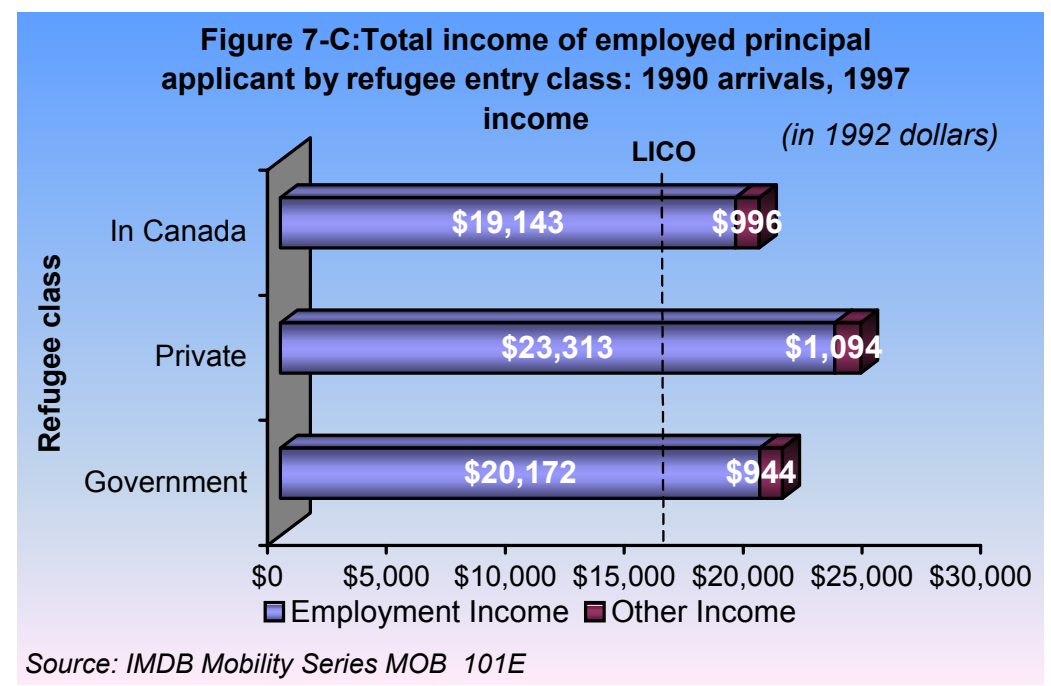

Moreover, there exists little absolute earnings differences across entry gates except for the privately sponsored 1985 and 1990 cohorts of refugees who did earn significantly more than other entry groups after seven years in Canada.

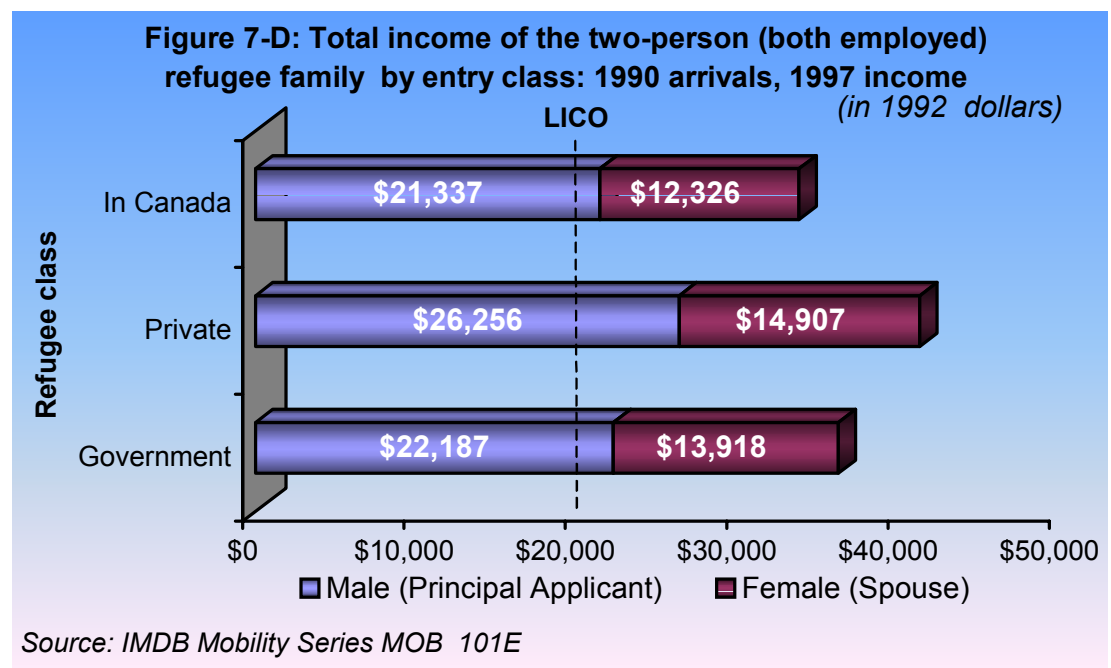


These refugee earnings performances greatly exceed the low income line (LICO) if we assume that both partners in a refugee household found employment. ${ }^{16}$ Figure 7-D demonstrates this point since the LICO rises only to 20,233 (1992 Canadian dollars), but combined male and female refugee employment earnings for the 1990 entry cohort ranges from $\$ 33,663$ to $\$ 41,163$ (1992 Canadian dollars).

Nonetheless, the absolute level of earnings for any entry group is not strong. Thus we must ask two further questions. How did other non-refugee entry groups to Canada fare after arrival in Canada? Furthermore, what effect did this weak and declining income-earning performance in general have on refugee poverty levels and use of Canada's social assistance programs? We answer these questions below.

\section{Refugee Economic Integration}

Previous research (DeVoretz 1995) has demonstrated the important effect of length of resettlement on economic performance. On average, it takes immigrants as a whole ten years to achieve their full economic potential. Analyses in this section describe the effects of time on economic performance for different immigrant classes.

\footnotetext{
${ }^{16}$ LICO for a two person urban household with greater than 500,000 population was \$20,233 (1992 Cdn dollars) in 1997.
} 


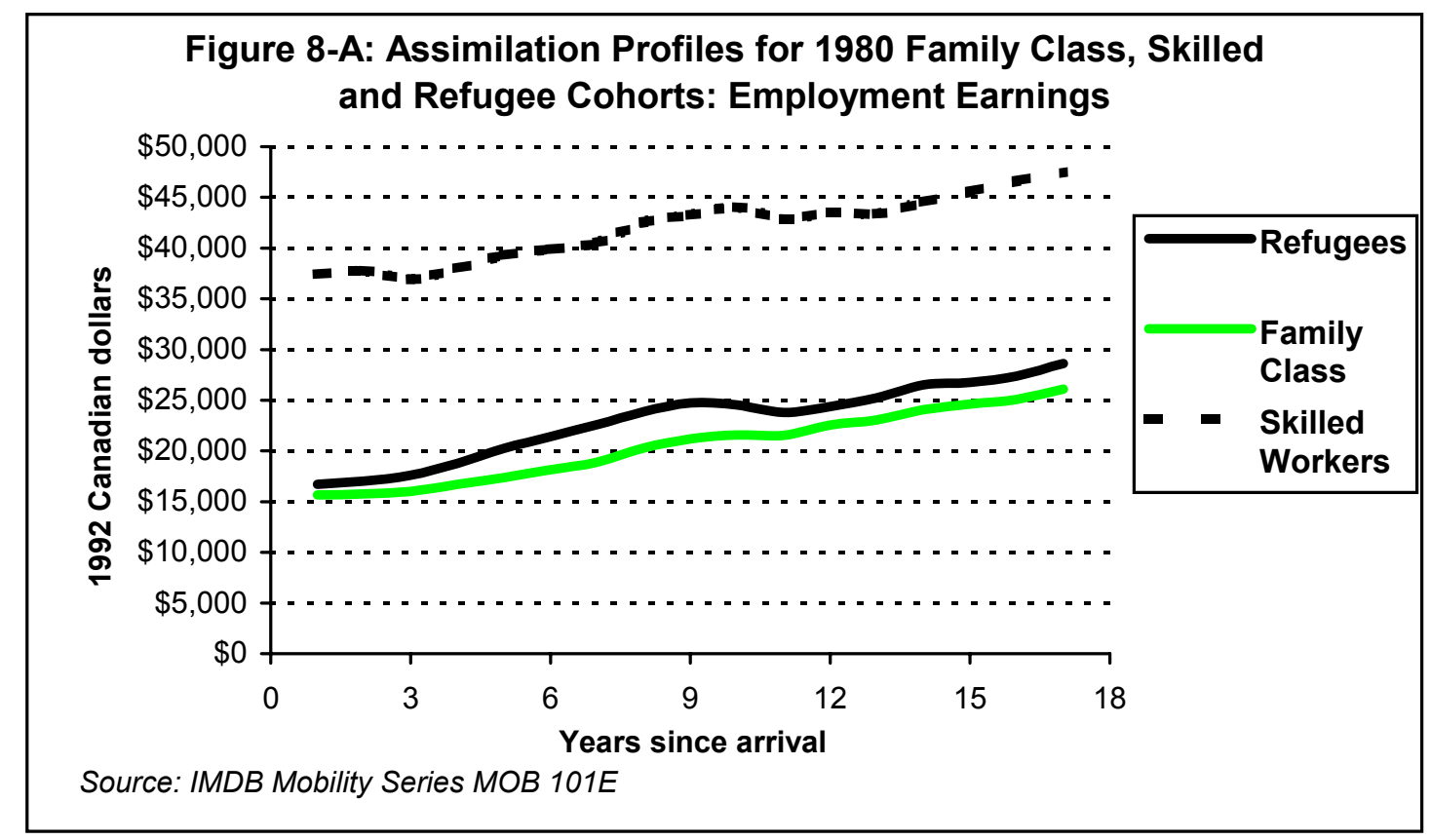

In particular, in this section we attempt to answer the earlier posed questions of degree of refugee economic integration by comparing refugee economic performance to family class immigrants over time. Figures 8-A and 8-B report the degree of refugee earnings integration in terms of years since arrival in Canada for both the 1980 and 1985 cohorts respectively. For the 1980 cohort, refugee employment earnings slightly exceed the earnings of family class members for the entire reporting period. ${ }^{17}$ Moreover, real (1992 dollars) employment earnings for the 1980 cohort of refugees doubled from 15,000 dollars to 30,000 dollars after 17 years in Canada. In both these dimensions, earnings relative to the family class and the growth in refugee earnings over time, it can be argued that the 1980 refugee cohort assimilated into the Canadian labour market. However, if we (incorrectly) used the doubly selected skilled worker group as the reference group, then the degree of refugee integration would be nil. In fact, the effect of double selection is made clear from the earnings of skilled workers who uniformly earn approximately $\$ 20,000$ more than the singly selected family and refugee classes for the 1980 cohort.

\footnotetext{
${ }^{17}$ Clearly these earnings are uncontrolled except for year of entry and entry class. However, that is our point.
} 
Figure 8-B reinforces this pattern of divergent earnings between the singly selected (refugee and family class) entrants and the doubly selected (economic) group with a second entry period cohort. However, it is clear that refugee integration performance for the 1985 cohort fell relative to the family class since their respective earnings are now equal. Moreover, since both Figures 8-A and 8-B portray identical earnings patterns over each relevant year after arrival, there appears to be no period effect during the $1980 \mathrm{~s}^{18}$

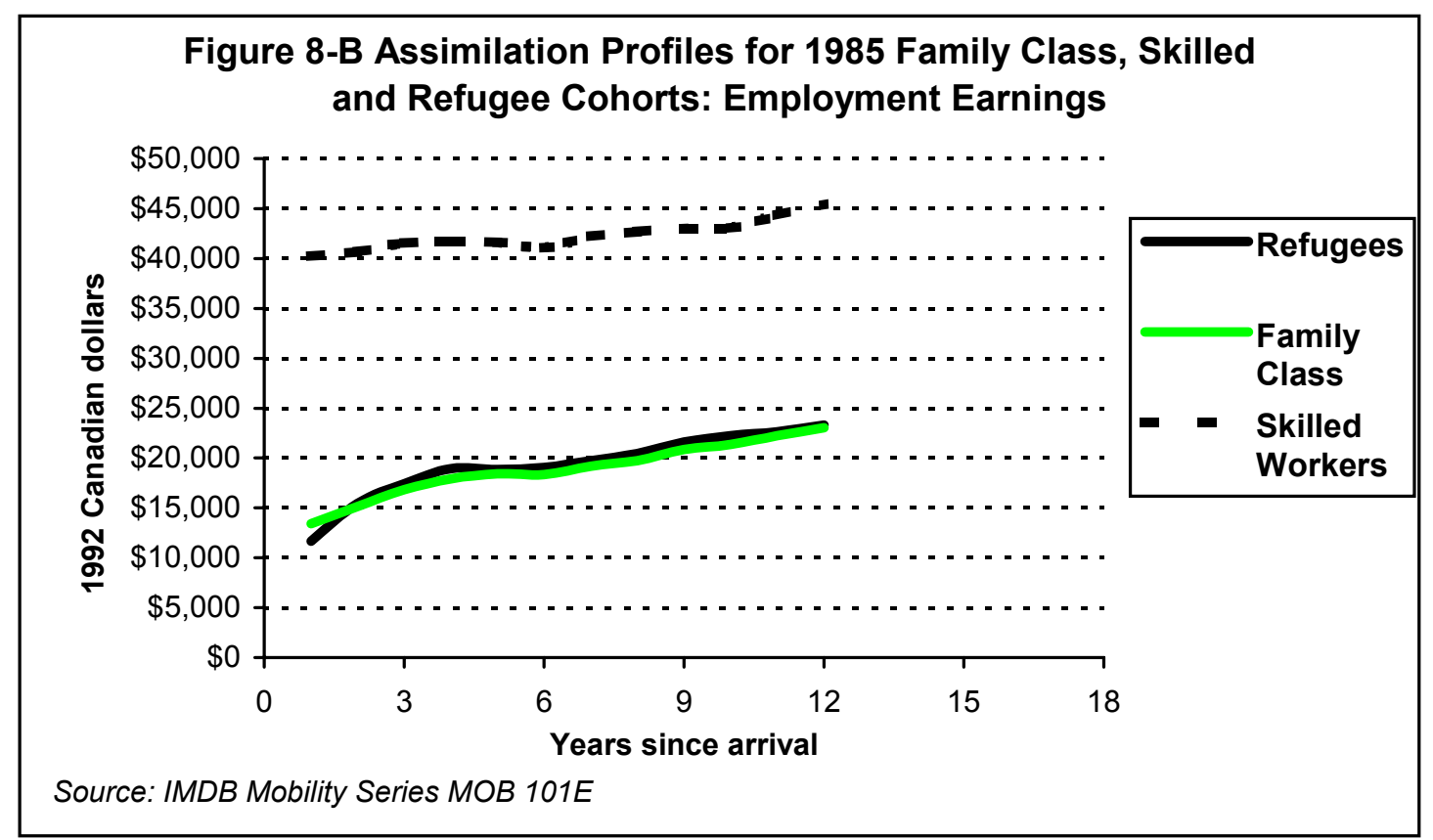

\section{Age-Earnings Profiles}

\footnotetext{
${ }^{18}$ There may be a period effect in the mid 1990's however the available IMDB data set does not allow us to construct meaningful years since arrival figures given the short time span of the data.
} 


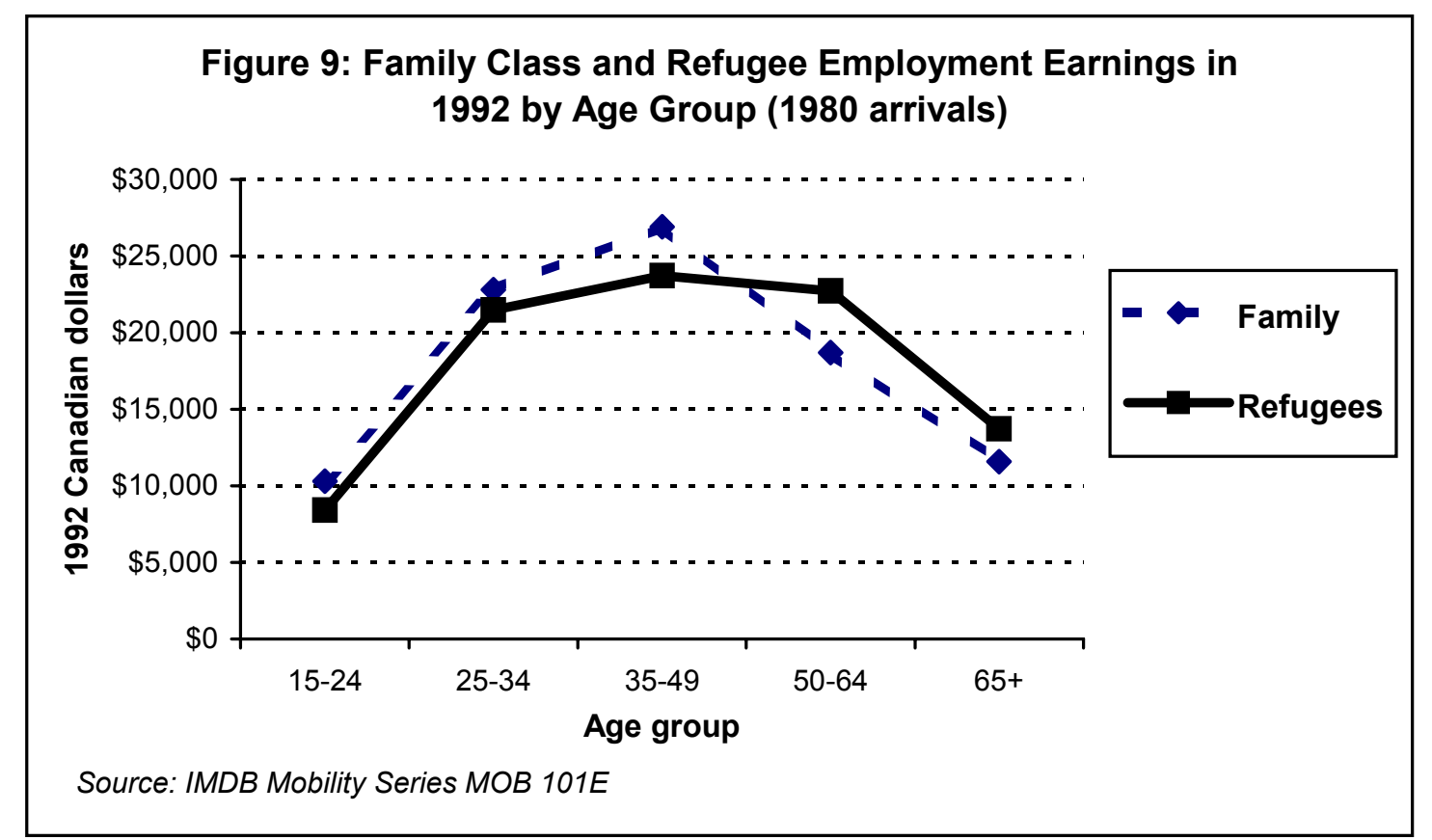

An alternative manner of measuring economic integration is to construct age earnings profiles for a given entry year (1980) cohort of the family class and refugee arrivals to test the human capital model of earnings. The human capital model would predict that these earnings profiles would be quadratic in form (i.e. concave) with a greater intercept for that group who acquired more human capital. The human capital model is supported by Figure 9, since both the family class and refugees' earnings performance follow the typical quadratic shape of age earnings profile predicted by the human capital model. Both groups' earnings initially rise as investment in language, etc. increases their productivity in Canada's labour market. A peak in earnings occurs at age interval 35-49 and then earnings decline to reflect the deterioration of human capital. Figure 9 also amplifies Figure 8-A findings that refugees and family class members have near-similar earnings performance. In particular, prior to age 40 , family class earners outperform refugees and then afterwards the trend is reversed.

\section{Regional Variations}

In addition to entrance category and time in Canada the place of settlement may exert an independent effect on economic performance (DeVoretz and Pivnenko 2004). The 
underlying proposition in this section is that either due to differential selection criteria or a weak economy (or both) Quebec-bound refugees would have a weaker performance. Also, it should be noted that to extent the Quebec-bound refugees are francophone they will have limited outmigration possibilities after arrival. ${ }^{19}$ All of these forces should contribute to differential regional refugee earnings. Table 1 presents two measures of earnings (employment earnings and total income) across the three provinces for employed refugees and family class entrants over time.

\footnotetext{
${ }^{19}$ See DeVoretz, Pivnenko and Coulombe (2003) for a more complete description of immigrant and refugee economic performance in Quebec.
} 


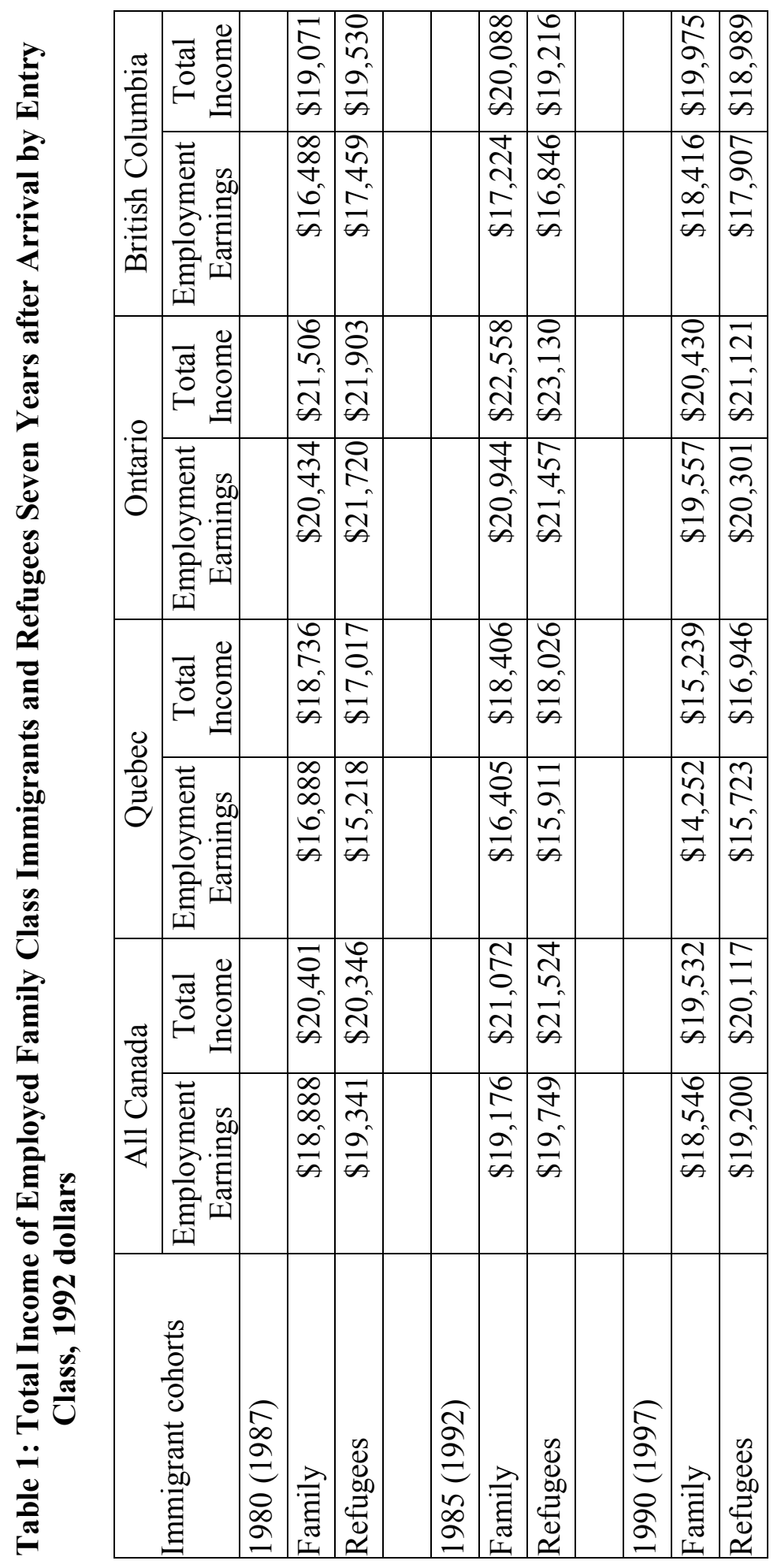


Ontario clearly offers superior income prospects for either refugees or family class entrants. The 1980 refugee cohort which lived in Ontario in 1987 earned 35\% (15\%) more in earnings than the 1980 refugee cohort resident in Quebec (British Columbia) in 1987 (Table 3 row 1). By 1997 the relative advantage of refugees living in Ontario versus Quebec and British Columbia slightly declined. Family class immigrants, our reference group, experienced a similar disparity in earning outcomes across provinces. However, contrary to the refugee experience these interprovincial income disparities grew between 1987 and 1997. In sum, after seven years in Canada earnings differentials persisted by province of residence for both refugees and the family class immigrants.

\section{Refugee use of Canada's Social Safety Net}

Earnings constitute an important measure of economic integration. To balance this measure, however, it is important to know to what extent refugees use Canada's social safety net. How do the successive refugee co-horts of 1980, 1985 and 1990 fare with respect to poverty levels? Canada has a relative poverty index or Low Income Cutoff (LICO) criterion which reports income levels for families or unattached individuals who spend $20 \%$ or more than the average on food, shelter and clothing. There are many experiments which we could perform to test if refugees receive a total income greater than LICO. In this case we choose a LICO based on single-family refugee household with one principal refugee applicant who was already employed. ${ }^{20}$ It is apparent from Figure 7-A that after seven years in Canada the 1980 refugee cohort, regardless of selection gate, earned on average a total income in excess of LICO. Subsequent cohorts in 1992 and 1997 also exceeded the poverty levels if they had reported earned income. What these diagrams indicate is that on average, refugees were not members of the working poor. However, this does not mean that those refugees who did not report employment earnings or belonged to a multiple-member household were not poor. We return to this important issue below. For purposes of completeness Figure10 reports that the family class or the reference group had a similar experience as the employed refugee group. In other words, if you arrived in Canada in the family class and reported earned income, on average you did not fall below the poverty line.

\footnotetext{
${ }^{20}$ The IMDB is our principal data source and does not allow use to compute household income for multiple earners units. Hence, we are restricted to an analysis of individuals.
} 


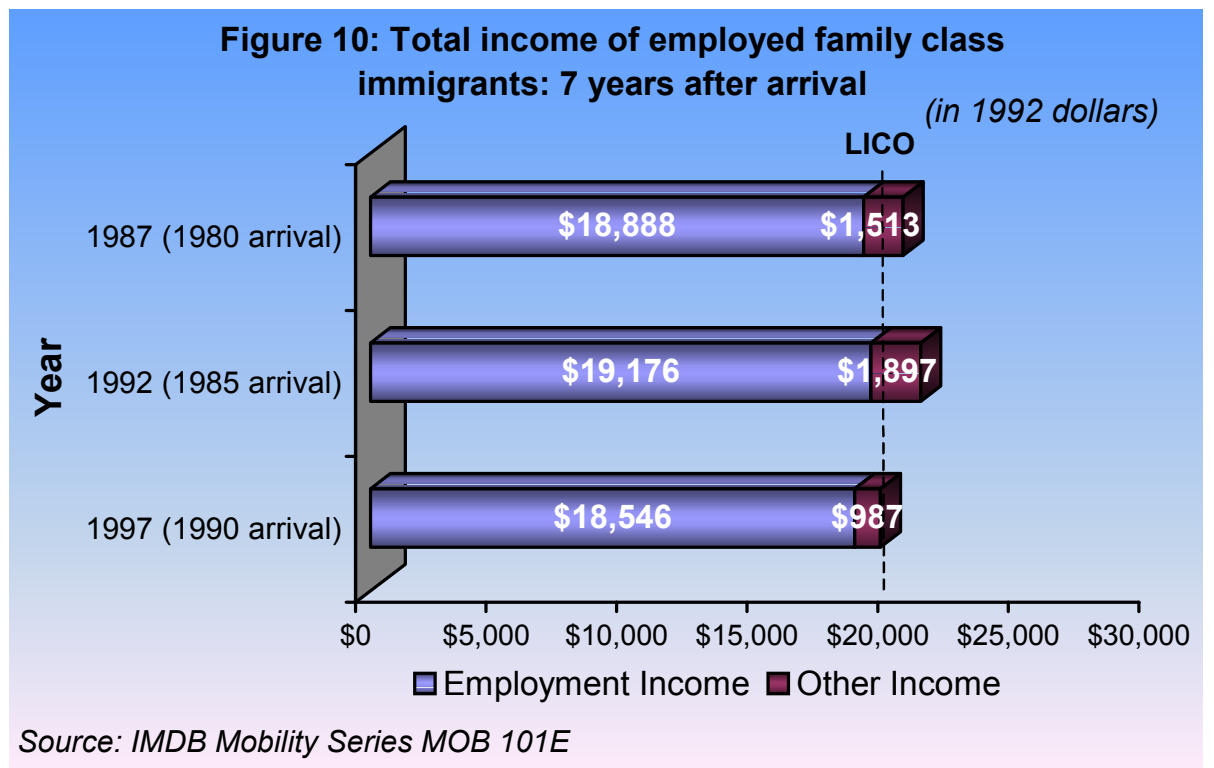

The concept of total income used in this analysis includes both earned income and government transfers for only those refugees who reported at least some earned income. ${ }^{21}$ This masks the true extent of refugee poverty in Canada. The analytical concept must be reversed for a more accurate picture. We must analyze the refugee group, which reported receiving some social assistance, then compute that dependent groups total income. Figures 11-A and 11-B report the total income of refugees (principal applicants) for the 1985 and 1990 arrival cohorts who first reported receipt of some social assistance. ${ }^{22}$

\footnotetext{
${ }^{21}$ See DeVoretz and Pivnenko (2004) for a complete analysis of Canadian federal government transfers to immigrants.

${ }^{22}$ Social assistance has been reported on the income tax form only since 1992.
} 

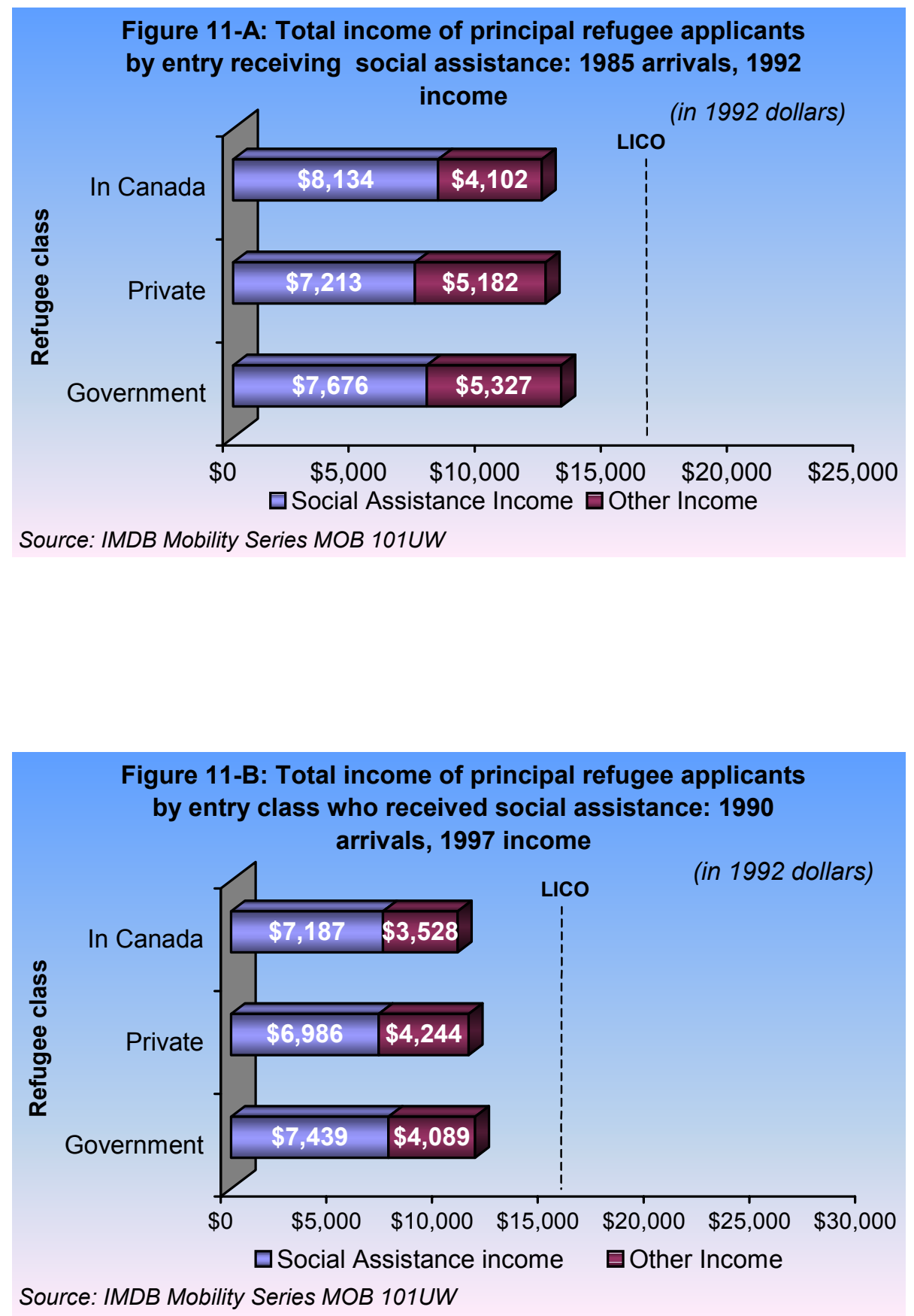

The experience of refugee social assistance recipients is vastly different for employed refugees in general (Figures 7-A to 7-C). For example, government-sponsored refugees who entered in 1990 and were employed in 1997 earned \$21,116 (1992 dollars, see Figure 7-C) while those government-sponsored refugees who arrived in 1990 and received social assistance in 1997 received a total income of only \$11,528. In short, in 1997 government- 
sponsored refugees who received some social assistance had a total income level that was only $70 \%$ of the LICO level. An additional disturbing finding embedded in Figures 11-A and $11-\mathrm{B}$ is that both earned income and social assistance declined in real terms across the cohorts between 1992 and 1997. In short, long-term refugee poverty (after seven years in Canada) worsened in the 1990s. Given these vastly different economic outcomes among all refugees on those who received some social assistance we now analyze the incidence of social assistance by refugee cohorts or entry gates.

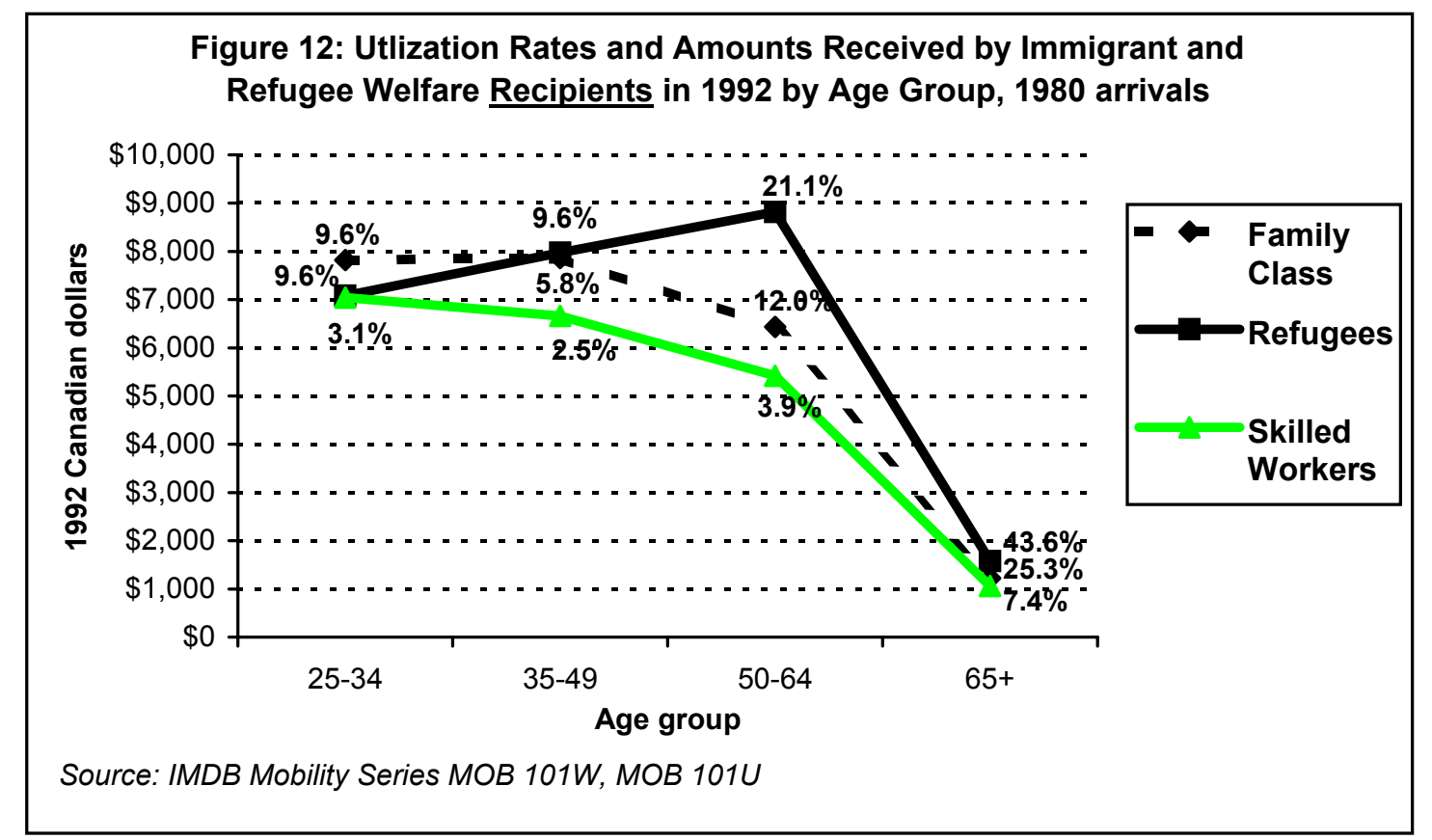

Figure 12 indicates that over their lifetime, refugee entrants have in general a greater risk of using welfare benefits than any other foreign-born entry category. In particular, during the peak earning years of 35-64 refugees have almost twice the incidence of welfare use as the similarly aged family class members. ${ }^{23}$ Beyond age 65 , the incidence of use of welfare by

\footnotetext{
${ }^{23}$ Different eligibility rules apply to the family and refugee classes for the collection of welfare. Family class members were denied by law in most cases access to welfare and when they do receive benefits their sponsors may be required to repay the government for these benefits. This rule did not apply to refugees.
} 
refugee claimants who arrived in 1980 rose to about $44 \%$ of that age group still resident in Canada in 1992.

Did refugees use welfare benefits to substitute for employment insurance benefits? In Canada, the normal procedure is to first utilize any insurance benefits that the worker paid for during periods of employment before social assistance or welfare could be claimed. Figure 13 lends some support to the view that refugees substitute welfare for insurance claims. As refugees age, their use of (Un)employment insurance declines from $32 \%$ in the $25-34$ aged group to $22.6 \%$ in the $50-64$ year old group. Nonetheless, refugees use employment insurance more than any other group and this reflects the weak employment prospects of refugees relative to either family or independent class immigrants who arrived in 1980.

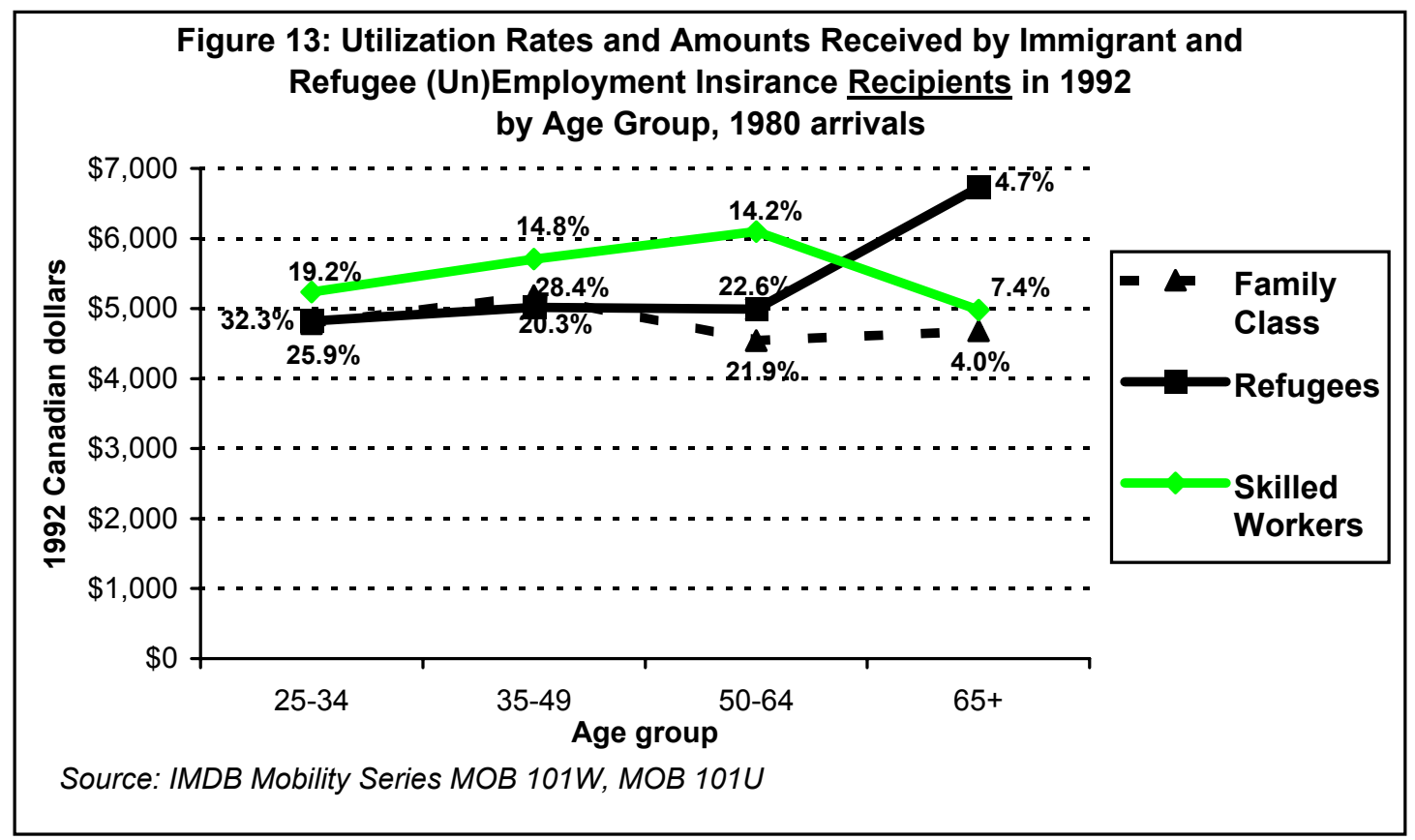

\section{Summary and Conclusions.}

This summary will answer the set of questions posed at the outset of this essay. We first asked if refugees experienced economic integration after a significant period of residence (seven years) in Canada. We offered two metrics to answer this question. We first measured refugee earnings relative to independent and family class immigrants over time in Canada and as the refugee group aged. In both dimensions, employed refugees on average 
have integrated into the Canadian economy. First, with respect to their reference group (family class) employed refugees earn an equal amount of income both at their time of arrival and in each successive year of residence.

We next asked if this performance varied by refugee date of arrival or across particular refugee entry gates. Evidence appears that refugees have been affected sometimes positively by their date of arrival during the 1980-1997 study period since the 1985 arrival group earned the highest income after seven years in Canada. There is some evidence that privately sponsored refugee earnings exceed other refugee groups over the study period. This may be because private sponsors have more time or motivation than the regular social system to help refugees find first jobs or help marginal people with their qualifications. Next, our major proposition that Canadian refugees follow a human capital model of earnings performance is supported by the available evidence.

Finally, even given this relatively strong economic performance of the average employed refugee, economic poverty was an endemic and growing problem for refugees. For those refugees who received social assistance, their total income level was extremely low or less than $\$ 12,000$ (1992 dollars) per refugee. This weak performance occurred seven years after their arrival! Thus, whether a refugee fared well in Canada's labour market ultimately depended upon employment prospects. Evidence from Canada's IMDB records for the study period indicates that only 52 percent of those refugees aged 20 to 64 found employment. Thus, the refugee population's earnings performance is truly bi-modal.

Economic outcome is probably dependent not only on human capital, but on opportunity. The regional differences in refugee economic integration suggest that local job market conditions affect refugees' chances of successful integration, regardless of human capital characteristics. Given the fact that federal policy is shifting to encourage provincial jurisdictions more autonomy in matters of refugee resettlement, further in-depth study of local conditions that promote or hamper economic integration should be a matter of high priority. 
Refugees are not, and should not be selected on the basis of their potential contribution to the Canadian economy. The data in this report demonstrate that, despite this fact, refugees do not constitute a major drain on the economy. Although their economic performance is not as impressive as that of independent immigrants, for whom human capital is the selection criterion, it is generally robust. However, although the economy may not be suffering, refugees - particularly the most recent arrivals - apparently are. Lower average wage earnings are consigning ever-greater proportions of refugees to the poverty ranks of Canadian society. This is a serious problem that calls for investigation of factors such as lack of recognition of credentials, and discrimination, which militate against finding jobs on the one hand, and job training programs and perhaps private sponsorship on the other, which may facilitate the integration process. 


\section{References}

Beiser, M. \& Hou, F. 2000. Gender Differences in Language Acquisition and Employment Consequences among Southeast Asian Refugees in Canada. Canadian Public Policy 26 (3): 311-330.

Citizenship and Immigration Canada. 1998. The Economic Performance of Immigrants: Immigration Category Perspective. IMDB Profile Series.

Cortes, K. E. 2001. Are Refugees Different from Economic Immigrants? Some Empirical Evidence on the Heterogeneity of Immigrant Groups in the United States. Center for Labor Economics, University of California at Berkeley. Working Paper No 41.

DeSilva, A. 1997. Earnings of Immigrant Classes in the Early 1980s in Canada: A Reexamination. Canadian Public Policy 23 (2): 179-202.

DeVoretz, D. J., ed. 1995. Diminishing Returns: The Economics of Canada's Recent Immigration Policy. Toronto: C.D. Howe Institute; and Vancouver: The Laurier Institution.

DeVoretz, D. \& Pivnenko. S. 2004. Immigrant Public Finance Transfers: A Comparative Analysis by City. Canadian Journal of Urban Research, in press.

DeVoretz, D., Pivnenko, S. \& Coulombe, D.S. 2003. The Immigration Triangle: Quebec, Canada and the Rest of the World. RIIM Working Paper No. 03-11. Vancouver: Simon Fraser University, Centre of Excellence, Immigration.

Shi, Y. 2003. The Impact of Canada's Immigration Act on Chinese Independent Immigration. RIIM Working Paper No. 03-07. Vancouver: Simon Fraser University, Centre of Excellence, Immigration. 